Hyaenognathus from the Late Pliocene of the Coso Mountains, California

Author(s): Chester Stock

Source: Journal of Mammalogy, Vol. 13, No. 3 (Aug., 1932), pp. 263-266

Published by: American Society of Mammalogists

Stable URL: https://www.jstor.org/stable/1374003

Accessed: 26-11-2019 23:47 UTC

JSTOR is a not-for-profit service that helps scholars, researchers, and students discover, use, and build upon a wide range of content in a trusted digital archive. We use information technology and tools to increase productivity and facilitate new forms of scholarship. For more information about JSTOR, please contact support@jstor.org.

Your use of the JSTOR archive indicates your acceptance of the Terms \& Conditions of Use, available at https://about.jstor.org/terms

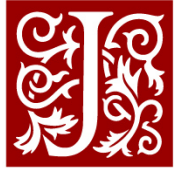

American Society of Mammalogists is collaborating with JSTOR to digitize, preserve and extend access to Journal of Mammalogy 


\section{HYAENOGNATHUS FROM THE LATE PLIOCENE OF THE COSO MOUNTAINS, CALIFORNIA}

\section{By Chester Stock}

\section{[Plate 14]}

Of the several occurrences of Hyaenognathus in the Pliocene and Pleistocene of North America three are recorded from California, one from the valley of Mexico, and one from Nebraska. To this list is now added a fourth occurrence in California based on a specimen from late Pliocene beds, exposed on the western flanks of the Coso Mountains, Inyo County, California.

While relatively few mammalian forms are now known from these deposits the fauna includes, in addition to Hyaenognathus, a new type of vole (Cosomys Wilson), a mastodon, Plesippus or Pliohippus, and a peccary.

\section{Hyaenognathus solus new species}

Type specimen.-No. 481, comprising chiefly the palatal portion of a skull with the superior dentition, plate $14, \mathrm{~A}$ and $\mathrm{B}$.

Specific characters.-Resembling Hyaenognathus matthewi Freudenberg more closely than $H$. dubius Merriam ( $H$. pachyodon Merriam). Differing from $H$. matthewi in smaller $\mathrm{I}^{3}$, less spacing of $\mathrm{P}^{2}$ and $\mathrm{P}^{3}$, and in greater forward direction of inner anterior root of $\mathrm{P}^{4}$.

Locality.-Calif. Inst. Technology Vert. Paleont. Loc. 131, Coso Mountains, $9 \frac{1}{2}$ miles east of Olancha, Inyo County, Calif.

This specimen is somewhat more complete than the type of Hyaenognathus matthewi described by Freudenberg ${ }^{1}$ from the Valley of Mexico. Our type is somewhat smaller than a cast of $H$. matthewi. There is likewise not much difference in this character between No. 481 and the skull fragment of Hyaenognathus dubius Merriam from Contra Costa County, California. ${ }^{2}$

In No. 481 all of the incisors with the exception of $\mathrm{I}^{2}$ are represented. As in the described species these teeth have strong, broad crowns, and $\mathrm{I}^{3}$ is distinctly larger than $I^{2}$. A narrow basal tubercle or cingulum is situated at the inner posterior base of the principal cusp in $\mathrm{I}^{3}$. In $H$. matthewi the third incisor, judged in the light of its alveolus, was probably larger than in No. 481. In relative size of $I^{8}$ No. 481 is more like $H$. dubius. Evidently associated with the smaller size of $\mathrm{I}^{3}$ is the slightly longer diastema between $\mathrm{I}^{3}$ and the canine in the specimen from the Coso Mountains than in the Mexican species. The crown of the canine is

${ }^{1}$ Freudenberg, W., Geol. u. Palae. Abh., vol. 13, pp. 209-214, pl. 24, figs. 3, 4, 1910.

${ }^{2}$ Merriam, J. C., Univ. Calif. Publ., Bull. Dept. Geol., vol. 3, pp. 283-288, pl. 30, fig. 1, 1903. 
relatively short and slender. It is sharply ridged anteriorly and posteriorly and these ridges define an outer and an inner surface. The former is broadly convex while the latter face is flatter with a median convexity extending the length of the crown.

No. 481 is distinctly more like the Mexican species and differs from Hyaenognathus dubius in the position of the anterior premolars. As in H. matthewi, the alveolus for $\mathrm{P}^{1}$ is situated farther forward with reference to the posterior border of the canine alveolus and more to the inner side than in $H$. dubius. Moreover, while in the latter $\mathrm{P}^{2}$ and $\mathrm{P}^{3}$ are in alignment with an axis extending from the anterior end of $\mathrm{P}^{4}$ to the posterior end of the canine, these teeth in No. 481 and in Freudenberg's specimen are distinctly oblique to this axis. In No. 481 the posterior end of $\mathrm{P}^{2}$ overlaps the antero-external surface of $\mathrm{P}^{3}$ and the two teeth are situated close together, whereas in the Mexican form the two premolars are separated by a short space.

The crowns of $\mathrm{P}^{2}$ and especially $\mathrm{P}^{3}$ are slightly narrower relatively to their long diameters than in Freudenberg's material. In contrast to $\mathrm{P}^{4}$, whose crown is considerably worn, the occlusal surfaces of $\mathrm{P}^{3}$ and $\mathrm{P}^{2}$ show practically no wear. Both crowns are better preserved than in the Mexican species. In both teeth the principal cusp and posterior basal cuspule are greatly subdued. The principal cusp tends to form a low ridge which extends to the anterior end of the tooth. A cingulum is present along the inner base of the crown in $\mathrm{P}^{3}$ and $\mathrm{P}^{2}$. In the type of $H$. matthewi the principal axis of $\mathrm{P}^{3}$ extends more directly transverse with reference to the anteroposterior axis of the palate than in the Californian form.

$\mathrm{P}^{4}$ agrees with the comparable tooth in $H$. matthewi and $H$.dubius in heaviness of shearing blade and absence of protocone. A parastyle is absent, the only indication of this structure being a short low ridge situated on the anterior surface of the paracone near the base. No. 481 is more like H.dubius and differs from H. matthewi in the extent to which the antero-internal root carries its crown in front of the anterior margin of the paracone. In the latter species the root does not project forward and $\mathrm{P}^{3}$ overlaps the anterior border of the protoconal region.

In the molar series considerable discrepancy in size is seen to exist between $\mathbf{M}^{1}$ and $\mathbf{M}^{2}$. The smallness of the posterior molar and anterior premolars gives added prominence to the intervening teeth, namely $\mathrm{P}^{4}$ and $\mathrm{M}^{1}$. The characters of the first molar are similar to those noted by Merriam in the comparable tooth of $H$. dubius. In No. 481 the shoulder at the antero-internal angle of the tooth is formed by a short cingulum. The fragmentary first upper molar of Hyaenognathus from the Tehama formation of northern California ${ }^{3}$ is smaller than the comparable tooth in No. 481. The crown of the second molar in the specimen from the Coso Mountains is characterized by a relatively broad central basin.

In $H$. matthewi the borders of the anterior palatine foramina are not preserved. These foramina in No. 481 are relatively small for the size of the palate. A well defined groove extends forward for some distance from each foramen. A single postpalatine foramen is present on each side of the palate on a level slightly in advance of the anterior borders of the first upper molars. Two foramina are

${ }^{3}$ Russell, R. D. and Vander Hoof, V. L., Univ. Calif. Publ. Bull. Dept. Geol. Sci., vol. 20, p. 19, fig. 7, 1931. 


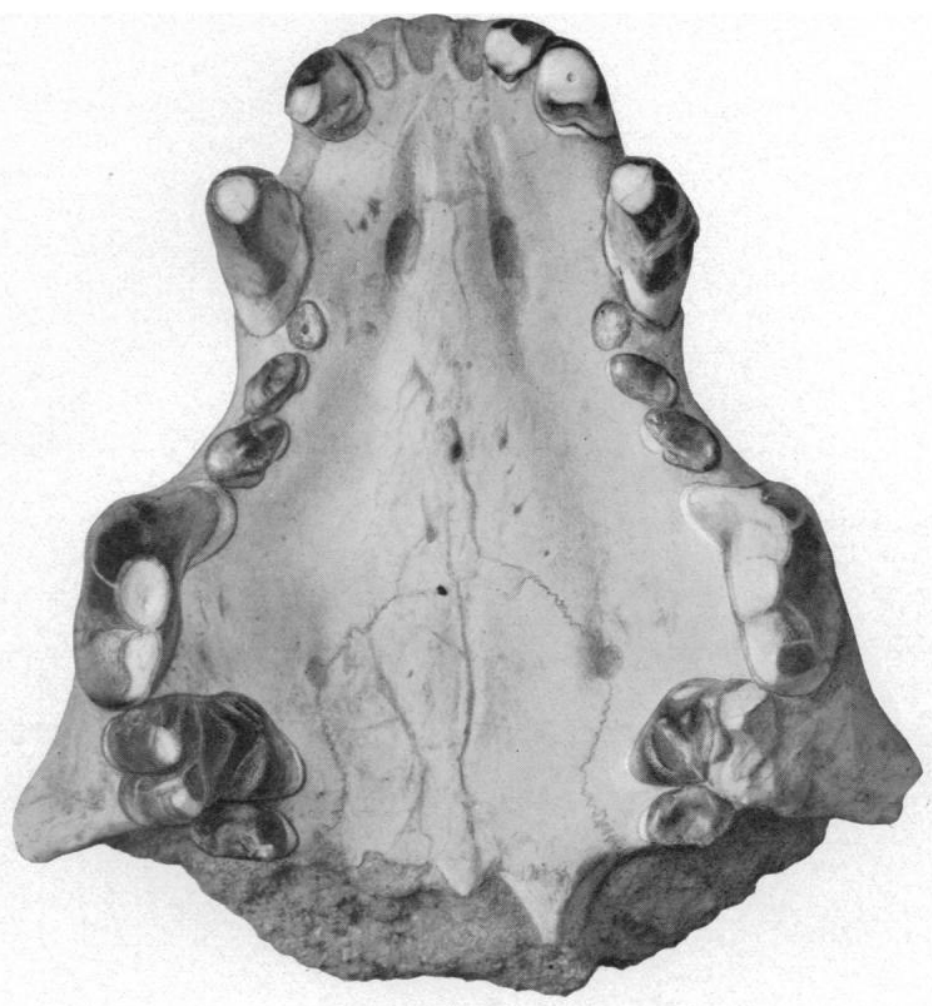

A

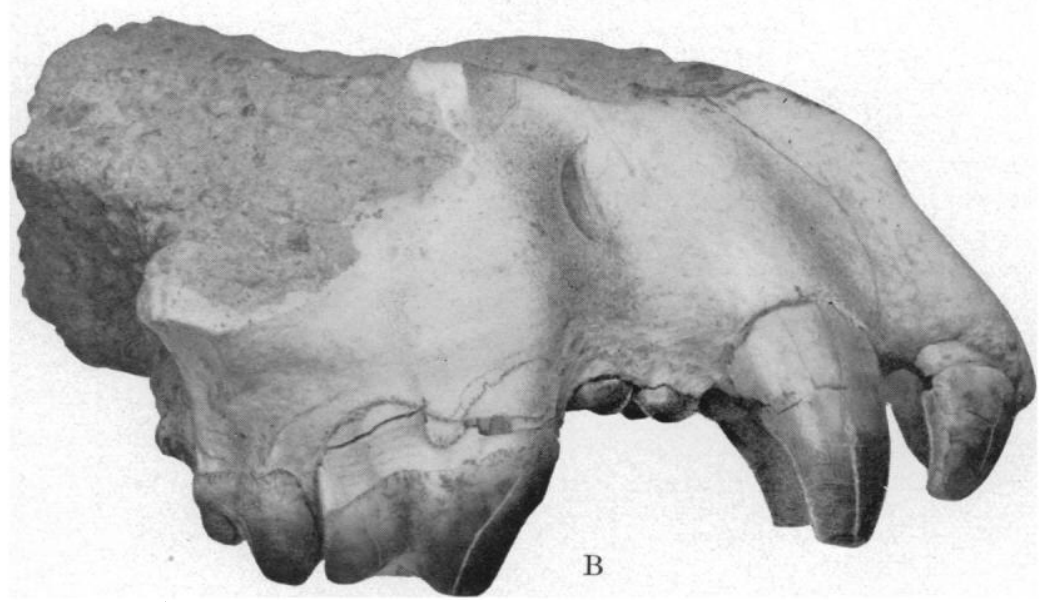

Hyaenognathus solus, new species; A, ventral view of rostrum, B, lateral view of rostrum. $\times \frac{3}{4}$. Cat. no. 481, Calif. Inst. Technology. Coll. Vert. Paleont.; Upper Pliocene, Coso Mountains, Calif. 
present on each side in $H$. dubius, but the openings have approximately the same position as in No. 481. The facial portion of the skull anterior to the fourth premolars is laterally constricted and as seen in side view (Plate 14, fig. B) the anterior opening of the infraorbital canal lies in the recessed wall of the maxillary above $\mathrm{P}^{3}$.

Of tre several species of Hyaenognathus recorded from the Pliqcene and Pleistocene two in addition to the one here described are known by the facial portion of the skull and upper dentition. ${ }^{4}$ In the position of the anterior premolars the form from Coso Mountains resembles $H$. matthewi more than it does $H$. dubius. The principal differences between the Mexican type and No. 481 lie in the spacing of $\mathrm{P}^{2}$ and $\mathrm{P}^{3}$, the more transverse position of the third premolar, less forwardly directed protoconal root of $\mathrm{P}^{4}$, and possibly larger size of $\mathrm{I}^{3}$. Notwithstanding these differences the two forms are closely related. $H$. dubius differs from No. 481 in the position of the anterior premolars and less forwardly directed protoconal root of $\mathrm{P}^{4}$.

While $H$. matthewi is recorded from the marls of Tequixquiac and has been regarded as of Pleistocene age, there is evidently some question as to the geologic horizon whence this specimen comes. Freudenberg has stated that the species is characteristic of the deepest strata at Tequixquiac which Felix and Lenk consider of upper Pliocene age. From the same horizon are recorded Aphelops and Preptoceras. The presence of the rhinoceros would further suggest a Pliocene age but the bovid genus Preptoceras has been found elsewhere only in typical Pleistocene faunas.

\section{Measurements (in millimeters) of No. 481}

Length from anterior end of premaxillary to median point of palatine border of posterior nares............... 108.5

Width of snout between outer alveolar borders of upper canines

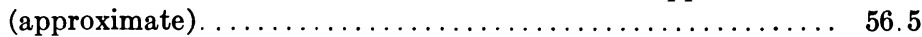

Width of face between maxillary surfaces covering outer anterior

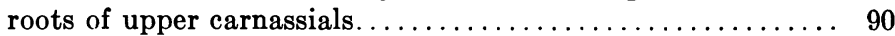

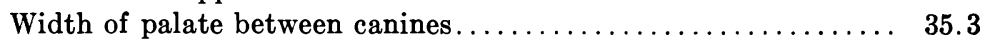

Least width of palate between first molars . . . . . . . . . . 39

Width across incisors measured between outer surfaces of lateral incisors . . . . . . . . . . . . . . . . . . 39

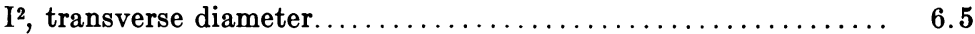

$\mathrm{I}^{2}$, anteroposterior diameter $\ldots \ldots \ldots \ldots \ldots \ldots \ldots \ldots \ldots \ldots \ldots . \ldots \ldots \ldots$

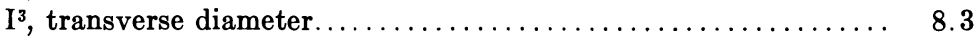

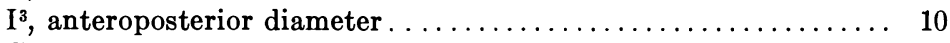

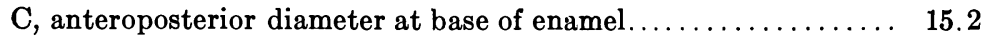

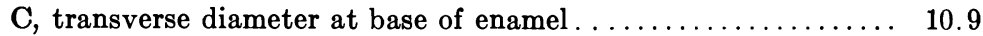

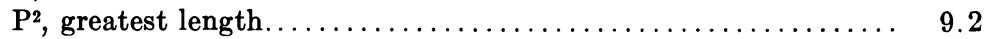

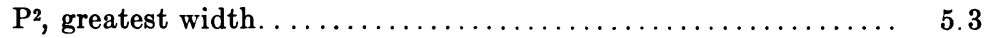

4 While the type of $H$. pachyodon consists of a lower jaw, topotype material recently secured by Mr. Vander Hoof at the locality near McKittrick, has been regarded by Matthew and Stirton as presenting sufficient evidence to indicate that $H$. dubius is specifically identical with $H$. pachyodon. 


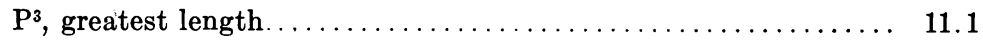

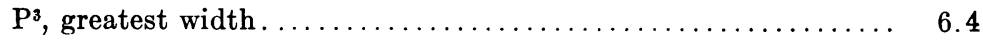

$\mathrm{P}^{4}$, anteroposterior diameter through middle of tooth......... 27.8

$\mathrm{P}^{4}$, transverse diameter across protocone. . . . . . . . . . . . . . 14.6

$\mathrm{M}^{1}$, anteroposterior diameter. . . . . . . . . . . . . . .

$\mathrm{M}^{1}$, greatest transverse diameter normal to plane of outer surface . $\quad 21.9$

$\mathrm{M}^{2}$, greatest anteroposterior diameter $\ldots \ldots \ldots \ldots \ldots \ldots \ldots \ldots, 8.1$

$M^{2}$, greatest transverse diameter $\ldots \ldots \ldots \ldots \ldots \ldots \ldots \ldots \ldots, 11.8$

Balch Graduate School of the Geological Sciences, California Institute of Technology.

\section{A NEW BEAVER FROM ARIZONA}

\section{By E. A. Goldman}

The beavers of Arizona have usually been assigned by recent authors to Castor canadensis frondator, which was described from the San Pedro River, Sonora, near the Arizona boundary. The material available for study is rather meager, but comparisons indicate that a hitherto unrecognized geographic race occurs along the Colorado River.

The new subspecies is described as follows:

\section{Castor canadensis repentinus subsp. nov.}

\section{COLORADO RIVER BEAVER}

Type.-From Bright Angel Creek, Grand Canyon of the Colorado River, Arizona (altitude 4,000 feet); no. 161613, $\&$ adult, U. S. National Museum (Biological Survey collection); collected by Clarence Birdseye, September 14, 1909; original number 723.

Distribution.-Vicinity of the Colorado River from the Grand Canyon to the delta; limits of range unknown.

General characters.-A light-colored subspecies closely allied to Castor canadensis frondator, of southeastern Arizona and northeastern Sonora, but upper parts paler, yellowish cinnamon, instead of near pecan brown (Ridgway, 1912) as in the type; cranial characters, especially the long nasals, distinctive. Similar to C.c. baileyi, of Nevada, but slightly paler, upper parts more yellowish, less rufescent; skull decidedly broader. Differing from C. c. mexicanus, of New Mexico, in slightly yellower coloration (duller brownish in mexicanus) and in cranial details, especially the longer, less expanded nasals.

Color of type.-Upper parts in general yellowish cinnamon, purest on rump and upper base of tail, this tone due to the long guard hairs overlying the under fur, which is near mars brown (Ridgway, 1912); flanks somewhat lighter than back; sides of muzzle, cheeks, sides of neck, forearms, and forefeet between pinkish 